\title{
Correction: T-type calcium channel enhancer SAK3 promotes dopamine and serotonin releases in the hippocampus in naive and amyloid precursor protein knock-in mice
}

\author{
Shuo Wang, Yasushi Yabuki, Kazuya Matsuo, Jing Xu, Hisanao Izumi, Kenji Sakimura, \\ Takashi Saito, Takaomi C. Saido, Kohji Fukunaga
}

In the Funding section, one of the grant numbers from the funder Scientific Research from the Ministry of Education, Science, Sports, and Culture of Japan is missing. The correct grant numbers are: Kakenhi 25293124 to K.F., 17K15456 to Y.Y. and 18J20651 to K.M.

\section{Reference}

1. Wang S, Yabuki Y, Matsuo K, Xu J, Izumi H, Sakimura K, et al. (2018) T-type calcium channel enhancer SAK3 promotes dopamine and serotonin releases in the hippocampus in naive and amyloid precursor protein knock-in mice. PLoS ONE 13(12): e0206986. https://doi.org/10.1371/journal.pone.0206986 PMID: 30571684

\section{G openaccess}

Citation: Wang S, Yabuki Y, Matsuo K, Xu J, Izumi H, Sakimura K, et al. (2019) Correction: T-type calcium channel enhancer SAK3 promotes dopamine and serotonin releases in the hippocampus in naive and amyloid precursor protein knock-in mice. PLoS ONE 14(1): e0211590. https://doi.org/10.1371/journal. pone. 0211590

Published: January 25, 2019

Copyright: ๑ 2019 Wang et al. This is an open access article distributed under the terms of the Creative Commons Attribution License, which permits unrestricted use, distribution, and reproduction in any medium, provided the original author and source are credited. 